\title{
An endocytic process in HEp-2 cells induced by enteropathogenic Escherichia coli
}

\author{
J.R. C. ANDRADE, V.F. DA VEIGA*, M. R. DE SANTA ROSA* and I. SUASSUNA
}

Serviço de Microbiologia e Immunologia, UERJ, 20550 Rio de Janeiro, and "Laboratorio de Microscopia Eletronica, Instituto de Microbiologia, UFRJ, 21941, Rio de Janeiro, RJ, Brasil

\begin{abstract}
Summary. Infection of HEp-2 cells by enteropathogenic Escherichia coli (EPEC) was examined by transmission and scanning electronmicroscopy. EPEC strains of serogroups $\mathrm{O} 111: \mathrm{K} 58$ and $\mathrm{O} 55: \mathrm{K} 59$ recently isolated from human patients did not exhibit enterotoxic activity, as judged by the Vero-cell and suckling-mouse assays, or invasive ability as judged by the Sereny test. These strains attached to and penetrated HEp- 2 cells. Transmission electronmicroscopy showed bacteria in close contact with cell membranes $15 \mathrm{~min}$ after infection; later, intense swelling and budding of membranes and penetration of EPEC into the cell cytoplasm occurred. Intracellular bacteria were enclosed in membrane-bound vacuoles in the cell cytoplasm underlying localised adherence sites observed by light microscopy. Scanning electronmicroscopy showed morphologically altered membranes only at the sites of bacterial attachment. Bacteria inactivated by ultraviolet light were not internalised and cytochalasin B ( $\geqslant 10 \mathrm{mg} / \mathrm{L})$ markedly inhibited uptake. These observations suggest that penetration of EPEC into HEp-2 cells occurs by an endocytic process in metabolically active bacteria.
\end{abstract}

\section{Introduction}

Certain serogroups of enteropathogenic Escherichia coli (EPEC) are associated with infantile enterocolitis and frequently cause diarrhoeal disease in conditions of poor hygiene (World Health Organization, 1980). Some authors (Konowalchuck et al., 1977; Klipstein et al., 1978; O'Brien et al., 1982) have demonstrated cytotoxic and enterotoxic properties in EPEC, but others (Echeverria et al., 1976; Levine et al., 1978; World Health Organization, 1980) have not.

In naturally infected human patients or experimentally infected animals, adhesion to enterocytes and effacement of microvilli are features of intestinal colonisation by human EPEC (Staley et al., 1969; Ulshen and Rollo, 1980; Rothbaum et al., 1982). Intracellular bacteria are usually limited to the apical cytoplasm of infected enterocytes (Staley et al., 1969; Ulshen and Rollo, 1980; Moon et al., 1983) and are associated with disorganisation of the cytoskeleton and loss of actin filaments (Rothbaum et al., 1982); the intracellular lesions are most readily seen in enterocytes densely colonised by

Received 14 March 1988; revised version accepted 1 June 1988.
EPEC (Staley et al., 1969; Moon et al., 1983; Peeters et al., 1984). EPEC strains also adhere to HEp-2 tissue-culture cells, whereas enterotoxigenic $E$. coli and $E$. coli strains from normal individuals do not (Cravioto et al., 1979; Baldini et al., 1983). The bacteria bind to cell surfaces and form microcolonies (Scaletsky et al., 1984). Such local adherence has been suggested as a virulence factor for EPEC (Nataro et al., 1985; Levine et al., 1985; Levine, 1987). We have previously suggested that EPEC infection of HEp-2 cells proceeds through two distinct, but functionally inter-related, stepsbacterial attachment to cell surfaces and internalisation of attached bacteria (Andrade and Santa Rosa, 1986a). Bacterial attachment mediated by non-fimbrial bacterial cell-surface adhesins and putative glycoprotein cell membrane receptors was a prerequisite for internalisation (Andrade and Santa Rosa, 1986b). Knutton et al. (1987) confirmed that EPEC adhered intimately to the HEp- 2 cell membrane and caused modifications of cell surface architecture that closely resembled EPEC adhesion to intestinal cells.

In the present study we have used scanning and transmission electronmicroscopy to investigate EPEC infection of HEp-2 cells. We also evaluated 
the effects of inactivation of EPEC by ultraviolet irradiation, and treatment of host cells with cytochalasin B, a drug which inhibits endocytosis.

\section{Materials and methods}

\section{Bacteria}

Six human isolates of $E$. coli were used. Some of their characteristics are listed in the table. EPEC serogrouping was performed with $\mathrm{OK}$ antisera (Difco). The bacterial strains were stored at $-25^{\circ} \mathrm{C}$.

Table. Characteristics of the E. coli strains used

\begin{tabular}{|c|c|c|c|}
\hline $\begin{array}{c}E . \text { coli } \\
\text { strain } \\
\text { no. }\end{array}$ & $\begin{array}{l}\text { Serogroup/ } \\
\text { serotype }\end{array}$ & Source & $\begin{array}{l}\text { levant surface } \\
\text { laracteristics }\end{array}$ \\
\hline 54 & O111:K58 & Sporadic case & non-pilate \\
\hline 68 & O55:K59 & Sporadic case & non-pilate \\
\hline 386 & O111:K58 & Outbreak & type-1 pili \\
\hline $3943-67$ & O111a, b:K58:NM & Stock culture & type-1 pili \\
\hline ECT-122 & O55:K59 & Stock culture & type-1 pili \\
\hline $\mathrm{F}-2$ & $\mathrm{O} ?: \mathrm{K} ?: \mathrm{H} 4$ & Normal faeces & non-pilate \\
\hline
\end{tabular}

\section{Virulence tests}

Bacterial invasiveness was tested in albino guinea-pigs by the Sereny test (Sereny, 1955) with bacteria grown on Brain-Heart Infusion Agar (Difco) or in media used for growth of EPEC before infection of cultured cells (see below). Animals were inoculated with $10^{8}-10^{10} \mathrm{cfu}$ or with a loopful of the agar-grown bacteria, and then observed over a period of $72 \mathrm{~h}$ for conjunctivitis or corneal clouding and ulceration. Tests for thermolabile enterotoxin (LT) and Vero-toxin (VT) were performed with Vero cells, according to the method of Konowalchuck et al. (1977). Production of heat-stable enterotoxin (ST) was evaluated by the suckling-mouse assay (Gomes et al., 1979). Cultures of virulent Shigella flexneri (1225/ 53), LT-positive $E$. coli (H10407), ST-positive $E$. coli (EC3) and VT-positive $E$. coli $(\mathrm{H} 30)$ were included as controls.

\section{Bacterial growth conditions}

Bacteria were grown for $16 \mathrm{~h}$ at $37^{\circ} \mathrm{C}$ in Trypticase Soy Broth (Difco); $500 \mu \mathrm{l}$ of such a culture was then mixed with $5 \mathrm{ml}$ of antibiotic-free Eagle's Minimal Essential Medium with Earle's salts (MEM: Gibco Laboratories), incubated for $2.5 \mathrm{~h}$ at $37^{\circ} \mathrm{C}$ to yield c. $3 \times 10^{8} \mathrm{cfu} / \mathrm{ml}$, and then added to cell monolayers.

\section{$U V$ inactivation of bacteria}

A 3-ml volume of bacterial culture in MEM was placed in an 85-mm plastic tissue-culture plate and exposed for $5 \mathrm{~min}$ to a UV light source $(15 \mathrm{~W}$ General Electric Germicidal Lamp) with gentle circular agitation. Irradiated bacteria were centrifuged and resuspended in MEM to achieve a concentration of $c .10^{8} \mathrm{cfu} / \mathrm{ml}$. Viability tests of UV-irradiated cultures yielded no growth.

\section{Cell-culture and infection}

The HEp-2 human epithelial cell line CCL 23 (American Type Culture Collection, Rockville, MD, USA) was cultivated in MEM supplemented with calf serum $10 \%$ $\mathrm{v} / \mathrm{v}$ (Instituto Adolfo Lutz, Sao Paulo) gentamicin $50 \mu \mathrm{g} /$ $\mathrm{ml}$ and amphotericin B $0.25 \mu \mathrm{g} / \mathrm{ml}$. Cells were grown in glass prescription bottles and were used after $24-48 \mathrm{~h}$ when growth was confluent. For scanning electronmicroscopy, monolayers were grown on $8 \times 8 \mathrm{~mm}$ glass coverslips.

Cell monolayers were thoroughly washed with Dulbecco's phosphate-buffered saline (PBS-D: $\mathrm{NaCl} 8.0 \mathrm{~g} / \mathrm{L}$, $\mathrm{KCl} 0.2 \mathrm{~g} / \mathrm{L}, \mathrm{Na}_{2} \mathrm{HPO}_{4} 1.15 \mathrm{~g} / \mathrm{L}, \mathrm{KH}_{2} \mathrm{PO}_{4} 0.2 \mathrm{~g} / \mathrm{L}$, $\mathrm{CaCl}_{2} 0 \cdot 1 \mathrm{~g} / \mathrm{L}, \mathrm{MgCl}_{2} 6 \mathrm{H}_{2} \mathrm{O} 0 \cdot 1 \mathrm{~g} / \mathrm{L} ; \mathrm{pH} 7 \cdot 2$ ). A $5-\mathrm{ml}$ suspension of bacteria $\left(3 \times 10^{8} \mathrm{cfu} / \mathrm{ml}\right)$ in MEM was then added carefully to monolayers. After incubation for $15 \mathrm{~min}$ at $37^{\circ} \mathrm{C}$ (contact stage), monolayers were washed twice with PBS-D prewarmed to $37^{\circ} \mathrm{C}$ and fresh antibiotic-free MEM was added. Monolayers were then incubated at $37^{\circ} \mathrm{C}$ for $30 \mathrm{~min}, 1 \mathrm{~h}, 4 \mathrm{~h}$ or $6 \mathrm{~h}$, with medium changes at 1 and $3 \mathrm{~h}$ to minimise extracellular bacterial growth. After the infection period, monolayers were washed twice with PBS-D and fixed with glutaraldehyde $3 \% \mathrm{v} / \mathrm{v}$. For tests of UV-treated EPEC, bacterial suspensions in MEM were incubated with cell monolayers for $2 \mathrm{~h}$ without medium changes.

\section{Treatment of HEp-2 cells with cytochalasin B}

Cytochalasin B (Sigma) was prepared as a $1 \mathrm{mg} / \mathrm{ml}$ stock solution in dimethyl sulphoxide (Sigma). This stock solution was diluted in MEM to achieve concentrations of $4,10,20,30$ and $40 \mu \mathrm{g} / \mathrm{ml}$ which were added to uninfected cell monolayers and held for $15 \mathrm{~min}$ at $37^{\circ} \mathrm{C}$. The infection procedure was $2 \mathrm{~h}$, as already described, except that MEM supplemented with cytochalasin $B$ was used and medium was changed at $1 \mathrm{~h}$.

\section{Transmission electronmicroscopy}

Infected monolayers were washed with PBS-D and fixed in cold $\left(4^{\circ} \mathrm{C}\right)$ glutaraldehyde $3 \%$ in $0.05 \mathrm{M}$ sodium cacodylate buffer $(\mathrm{pH} \mathrm{7.2)}$ for $1 \mathrm{~h}$. Cells were gently scraped with a rubber policeman and washed thrice with sucrose $9 \% \mathrm{w} / \mathrm{v}$ in $0.05 \mathrm{M}$ cacodylate buffer $(\mathrm{pH} 7 \cdot 2$ ). Cell pellets were embedded in Noble Agar (Difco) $1 \% \mathrm{w} / \mathrm{v}$ in $0.85 \% \mathrm{NaCl}$ and small blocks were cut, fixed in $1 \%$ osmium tetroxide, dehydrated in a graded series of 
ethanol $(50-100 \%)$, treated with uranyl acetate $0.5 \%$ and embedded in Polylite 8001 according to the method of Coiro et al. (1972). Ultrathin sections were cut on an LKB Ultratome $\mathrm{V}$, stained with aqueous uranyl acetate $1 \% \mathrm{w} / \mathrm{v}$ and lead citrate (Reynolds, 1963) and viewed with a Phillips EM 301 microscope at 60-100 kV.

\section{Scanning electronmicroscopy}

After $30 \mathrm{~min}$, infected cell monolayers on $8 \times 8 \mathrm{~mm}$ coverslips were gently washed with PBS-D, fixed in glutaraldehyde-cacodylate buffer for $5 \mathrm{~min}$ at room temperature and were washed thrice with sucrosecacoylate buffer. Coverslips were covered with osmium tetroxide $1 \%$ and held for $10 \mathrm{~min}$ at $25^{\circ} \mathrm{C}$, washed thrice with distilled water, dehydrated through ascending concentrations $(50-100 \%)$ of ethanol and dried by critical point drying. The specimens were then sputter-coated with gold and viewed with a JEOL JSM 25 II scanning electronmicroscope operated at $25 \mathrm{kV}$.

\section{Results}

\section{Virulence tests}

None of the $E$. coli strains was positive in tests for heat stable toxin or caused morphological alterations characteristic of thermolabile or Vero toxins in Vero cells. No significant lesions were detected in the Sereny test with organisms grown either in liquid or on agar media.

\section{Infection of HEp-2 cells}

Giemsa-stained monolayers of HEp- 2 cells infected by EPEC strains 54, 68 and 386, and observed by light microscopy, revealed the characteristic pattern of adhesion designated "localised adherence" in which bacteria were attached in discrete clusters (fig. 1).

Scanning electronmicroscopy of cell monolayers infected for $30 \mathrm{~min}$ with the non-pilate EPEC strains 54 and 68 showed bacterial clusters distributed on cell surfaces. Abundant filiform and digitiform projections were observed beneath the sites of bacterial attachment. Regions of plasma membrane around bacterial clusters appeared normal with small microvilli (fig. 2). HEp-2 cells infected with the pilate strain 386 showed isolated bacteria as well as clusters. Membrane budding around attached bacteria and signs of bacterial internalisation were also noted for the isolated bacteria. Most pilate bacteria displayed filiform

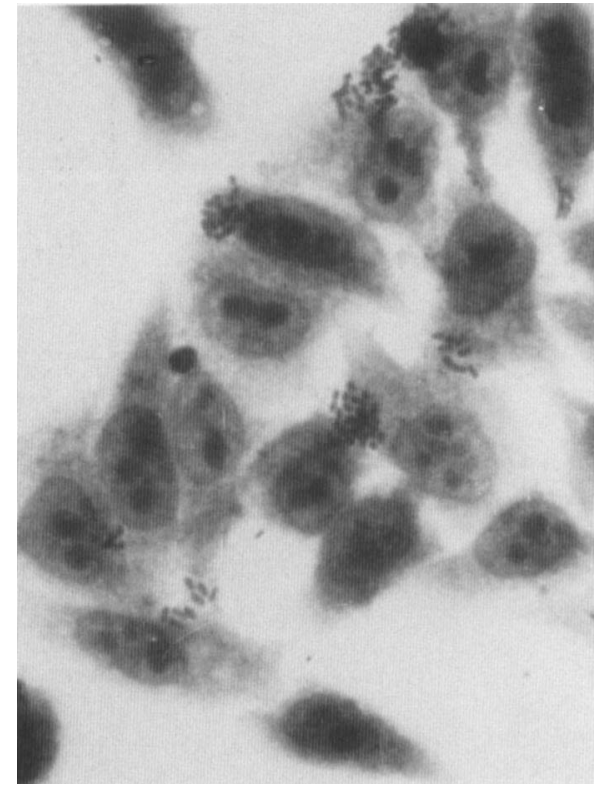

Fig. 1. E. coli 54 , showing "localised adherence" to HEp-2 cells. Giemsa, $\times 870$.

projections binding the bacterial surfaces to the subjacent plasma membrane (fig. 3).

Transmission electronmicroscopy of cells $15 \mathrm{~min}$ after addition of non-pilate EPEC strains 54 and 68 showed bacteria separated from the plasma membrane by a gap of $0.01 \mu \mathrm{m}$. At the points of contact, the membrane showed an increase in density and was frequently cupped along the adherent bacterium (fig. 4). At this time, most bacteria were extracellular, but a few were observed to be intracellular or undergoing internalisation. Digitiform projections frequently entangled celladherent bacteria (figs. 4 and 5). Ultrastructural signs of cell damage were not detected. Thirty minutes after infection, most bacteria were undergoing internalisation (fig. 5). From 1 to $4 \mathrm{~h}$ after infection, penetration of EPEC organisms into the cytoplasm of cells was seen frequently, with individual bacteria enclosed in membranebound vacuoles (fig. 6 ). These vacuoles appeared to fuse as they moved to the perinuclear region giving rise to larger vacuoles containing several bacteria (fig. 7). The major cellular alterations at $2 \mathrm{~h}$ and $4 \mathrm{~h}$ consisted of intense swelling and budding of plasma membrane beneath and in the immediate neighbourhood of the attached EPEC. Bacteria that appeared to be dividing were observed inside 


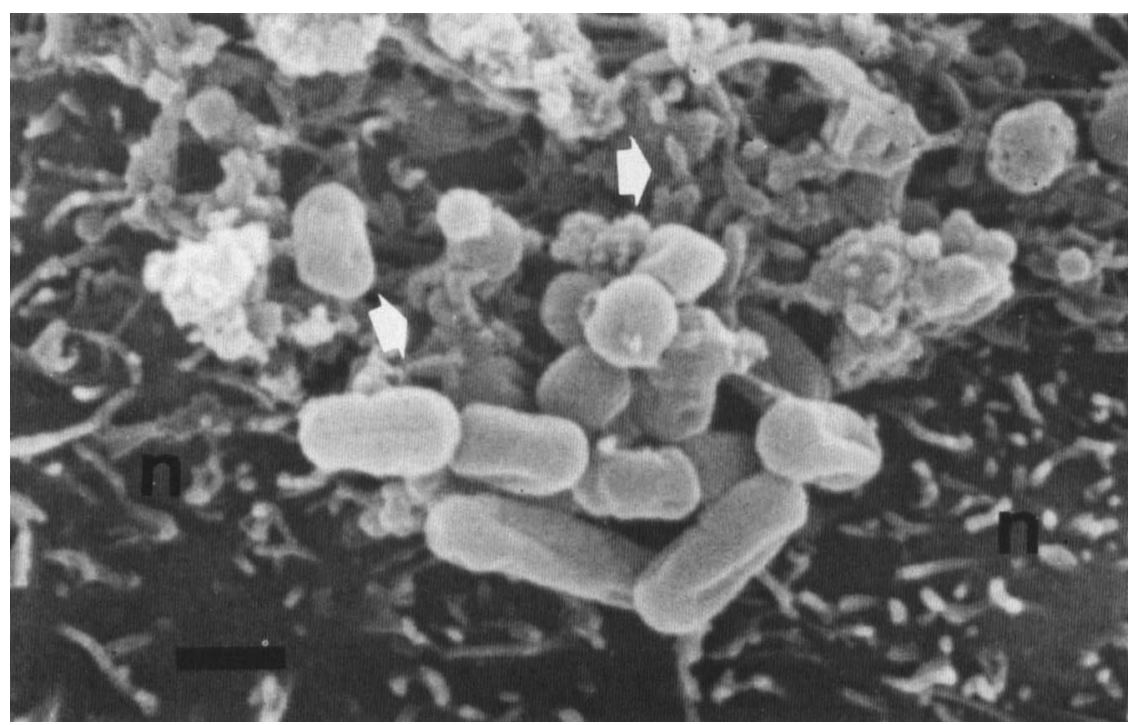

Fig. 2. Scanning electronmicrograph of HEp-2 cell infected with $E$. coli 54. Bacilli are clumped together. Digitiform projections (arrows) are present adjacent to the aggregates of bacteria. Cell membrane around bacterial clusters appears unaltered (n). Bar, $1.0 \mu \mathrm{m}$.

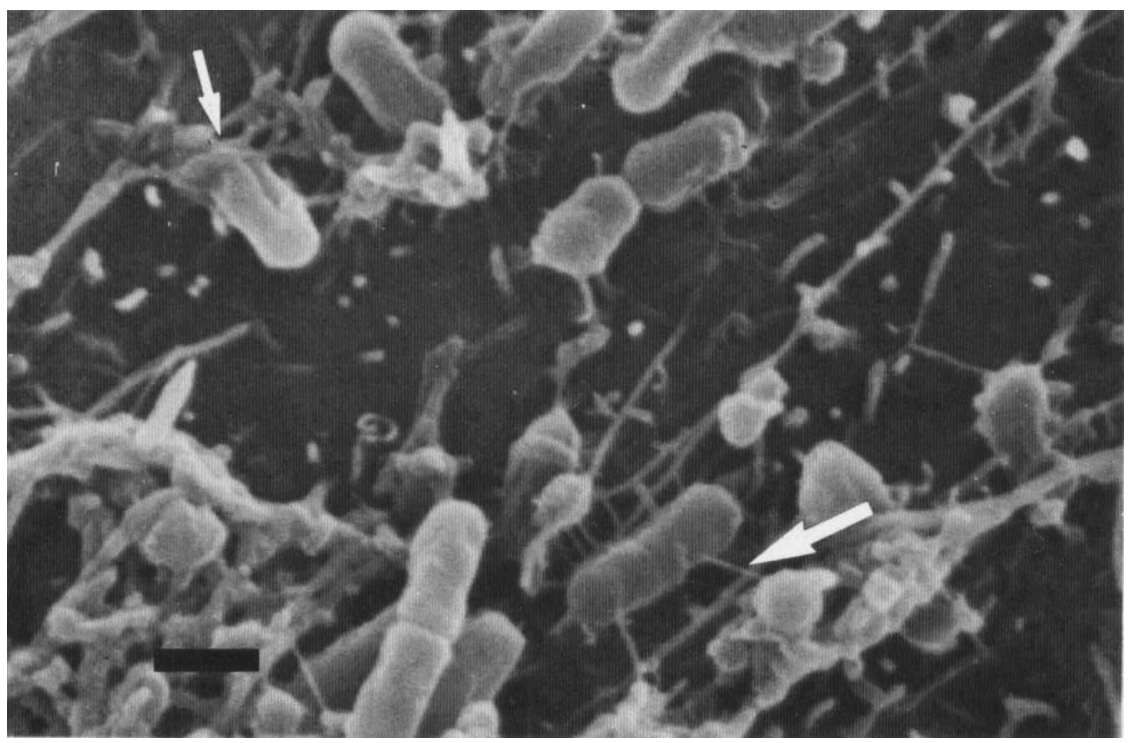

Fig. 3. Scanning electronmicrograph of HEp-2 cell infected with type-1 pilate $E$. coli 386 . Cell-membrane projections arise from regions adjacent to individual bacilli attached to the cell surface. Some bacteria seem to be undergoing internalisation (small arrow). Filiform projections suggesting bacterial pili seem to make contact with the cell surface (large arrow). Bar, $1 \cdot 0 \mu \mathrm{m}$.

vacuoles and others lay free in the cytoplasm apparently without membrane enclosure (fig. 7).

Infection of HEp-2 cells with type 1-pilate EPEC strain 386 showed similar ultrastructural changes, but more bacteria were attached to cell surfaces.
Most adherent bacteria were closely associated with the plasma membrane. At $6 \mathrm{~h}$ after infection, extensive destruction of cell monolayers occurred; the remaining cells were full of intracellular bacteria and were severely damaged. 


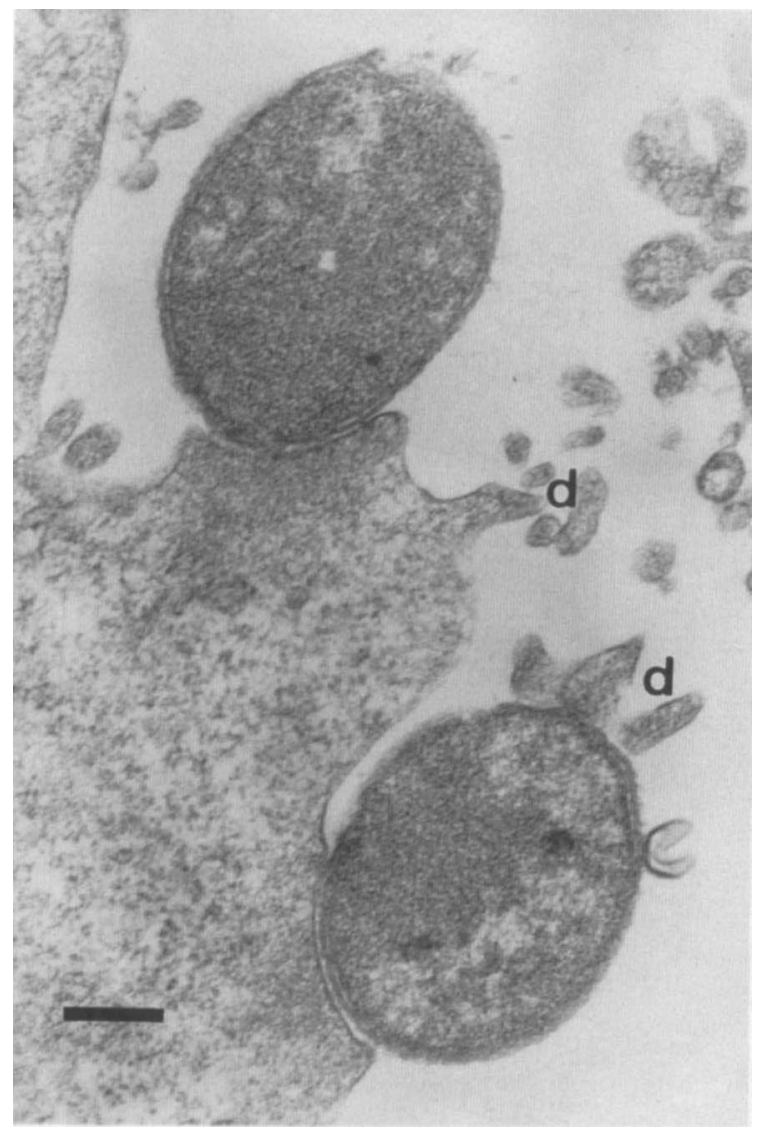

Fig. 4. Transmission electronmicrograph of HEp-2 cell $15 \mathrm{~min}$ after infection with $E$. coli 54 . A small gap $(0.01 \mu \mathrm{m})$ separates closely apposed bacterial and cell surfaces. Terminal web is dense under site of bacterial attachment. Cell membrane forms cups at the base of attached organism. Digitiform projections (d) arise from regions closely adjacent to attachment site and bind to bacterial surface. Bar, $0 \cdot 2 \mu \mathrm{m}$.

Non-EPEC strain F-2 and EPEC stock strains 3943-67 and ECT 122 did not exhibit localised adherence and binding to cell surfaces was rarely found. At the infrequent points of contact between bacterial and cell surfaces, modification of the plasma membrane did not occur. No penetration into cell cytoplasm, induction of alterations to the membrane or other cell damage was observed.

\section{$U V$ irradiation of EPEC}

UV irradiated EPEC strains did not penetrate HEp-2 cells during the time of the experiment. A few bacteria were found separated from the epithelial cell surfaces by a $0.01 \mu \mathrm{m}$-gap, but alterations of plasma membrane at the sites of bacterial binding were not seen.

\section{Effect of cytochalasin B on HEp-2 infection}

Cytochalasin B at a concentration of $4 \mu \mathrm{g} / \mathrm{ml}$ did not inhibit internalisation of EPEC by HEp-2 cells. However, a reduction in the number and length of digitiform projections and membrane pedestals beneath the attached bacteria was noted. Concentrations of 10 or $20 \mu \mathrm{g} / \mathrm{ml}$ caused a substantial reduction in the number of HEp- 2 cells with intracellular bacteria and in the number of bacteria internalised; polybacterial vacuoles were rarely found. Cytochalasin concentrations of 30 and $40 \mu \mathrm{g} /$ $\mathrm{ml}$ almost completely abolished bacterial internalisation. Cells containing isolated bacteria in small vacuoles were occasionally found.

\section{Discussion}

These results and earlier findings suggest that infection of HEp-2 cells by EPEC correlates with virulence of recently isolated strains : non-enteropathogenic $E$. coli and EPEC stock cultures did not undergo internalisation even when larger bacterial numbers $\left(10^{9}\right.$ and $\left.10^{10} \mathrm{cfu} / \mathrm{ml}\right)$ and longer incubation periods were used in cell infection assays.

Internalisation of EPEC by HEp- 2 cells differs from invasion by Shigella spp. or entero-invasive $E$. coli. Thus, despite the use of conditions favourable for bacterial internalisation, none of our EPEC strains showed entero-invasive ability as judged by the Sereny test. Microscopy of stained monolayers of HeLa or Henle cells infected by entero-invasive $E$. coli or Shigella spp. show elongated bacteria scattered throughout the cytoplasm after incubation for 5-8 $\mathrm{h}$ and bacterial clumps are not found at an early stage of infection (Gerber and Watkins, 1961 ; Ogawa et al., 1967, 1968; Calabi, 1970). Marked ultrastructural differences also occur. Shortly after infection of cultured cells by Shigella spp. (Hale et $a l ., 1979$ ) and entero-invasive $E$. coli (Knutton et al., 1984) a few bacteria attach to cell surfaces or become intracellular, but it is possible to observe unequivocal bacterial penetration only after several hours. Moreover, only minor alterations of the plasma membranes are seen at any time. In contrast, EPEC infection of cultured cells results in a marked early mobilisation of plasma membrane at the points were micro-organisms are intimately attached to the cell surface.

Adherence of EPEC organisms is a prerequisite for bacterial internalisation into HEp-2 cells; non- 


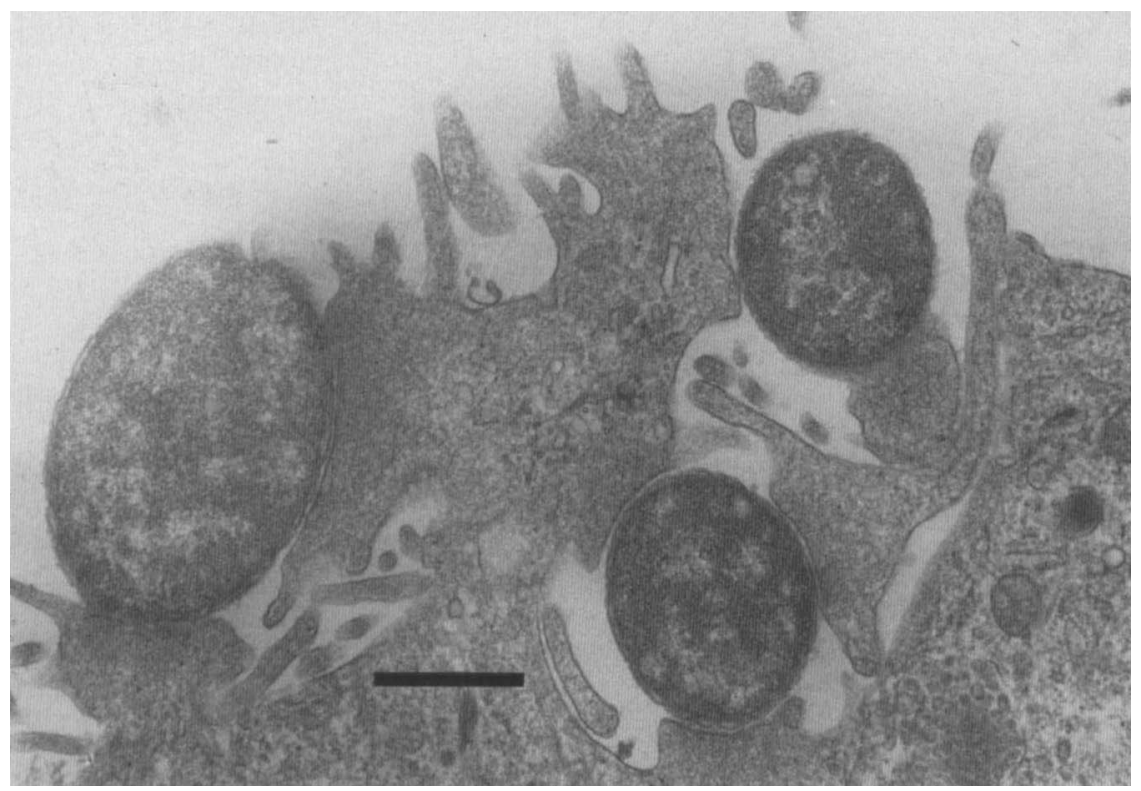

Fig. 5. Transmission electronmicrograph of HEp-2 cell $30 \mathrm{~min}$ after infection with $E$. coli 54 . Marked formation of digitiform projections and membrane folding occurs at or near the bacterial attachment site. Some bacteria are undergoing internalisation. Bar, $0.5 \mu \mathrm{m}$.

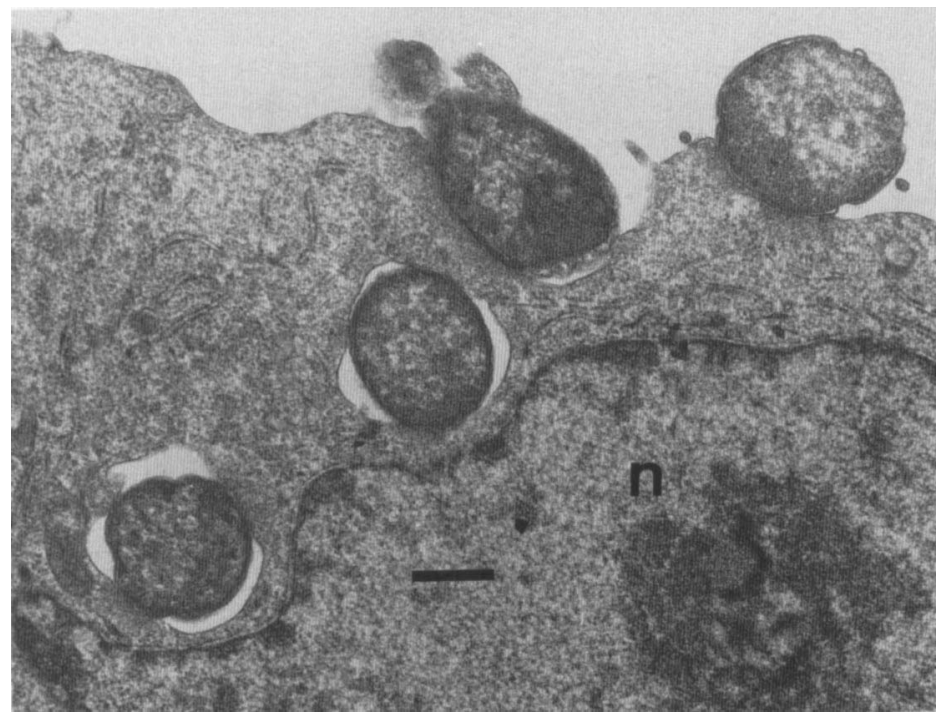

Fig. 6. Transmission electronmicrograph of HEp-2 cell $2 \mathrm{~h}$ after infection with $E$. coli 68 . Intracellular bacteria are enclosed in membrane-bound vacuoles that seem to migrate to the nuclear region. Bacterial vacuoles cause a marked depression on nuclear membrane; $\mathrm{n}=$ cell nucleus. Bar, $0.42 \mu \mathrm{m}$.

fimbrial, haemagglutination-negative bacterial adhesins mediate attachment to the cell surface (Andrade and Santa Rosa, 1986a, 1986b). Adherence is specifically blocked by galactose, glucose and rhamnose and even among EPEC strains of the same serogroup a great diversity of adhesins is anticipated from sugar-inhibition adherence tests (Andrade and Santa Rosa, 1986b). Such EPEC adhesins were called endocytosis-inducer adhesins to emphasise their contribution to bacterial pene- 


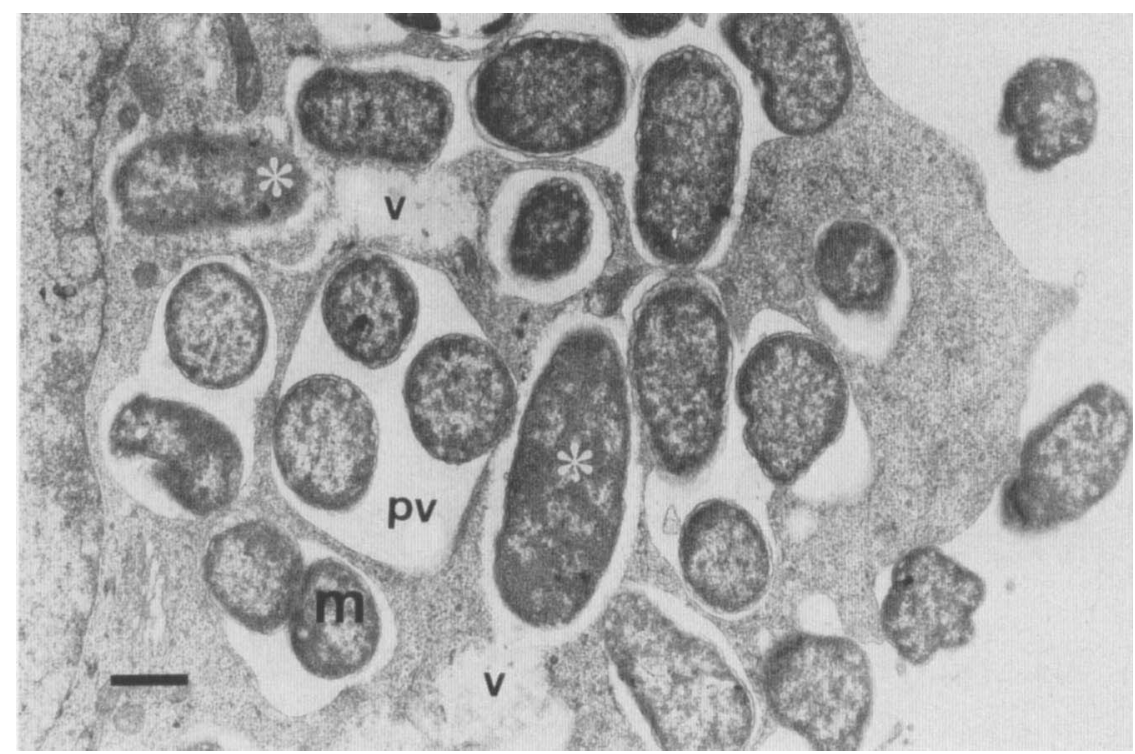

Fig. 7. Transmission electronmicrograph of HEp-2 cell $4 \mathrm{~h}$ after infection with $E$. coli 54 . Organisms accumulate in cell cytoplasm beneath attachment site. Large polybacterial vacuoles (pv) and multiplication of intracellular micro-organisms (m) are shown. Some bacteria are in direct contact with cell cytoplasm (*). Small vacuoles (v) suggest cell damage. Bar, $0.54 \mu \mathrm{m}$.

tration into cultured cells (Andrade and Silva, 1987).

Once attached to plasma membrane, viable EPEC were rapidly internalised. The uptake of particulate material by cultured cells occurs by endocytosis, implying active mobilisation of plasma membrane by interaction between actin filaments and myosin, the main components of the cell contractile system. Cytochalasin B hinders the addition of actin molecules to actin filaments leading to their depolymerisation, with inhibition of endocytosis and cell locomotion, membrane ruffling and interference with the formation of microvilli or microspikes (Allison et al., 1971; Alberts et al., 1983). Treatment of HEp-2 cells with cytochalasin $\mathrm{B}$ inhibited the formation of digitiform projections and membrane budding and halted internalisation of EPEC without any significant decrease in bacterial attachment to plasma membrane.

Internalisation of EPEC seems to proceed through an endocytic process requiring metabolically active bacteria, since UV-inactivated EPEC bound to but were not internalised by HEp-2 cells. Bacterial viability also plays an essential role in penetration of Sh. flexneri and S. typhimurium into human epithelial cells (Kihlström and Edebo, 1976; Kihlström and Nilsson, 1977; Hale and Bonventre,
1979). Viable EPEC probably induce some kind of interference in the actin-myosin cell contractile network at the sites of bacterial attachment leading to a local proliferation of cell extensions and membrane budding and infolding. Scanning electronmicroscopy of infected cells showed marked membrane mobilisation only at sites of bacterial attachment.

Small intestinal cells of infants (Ulshen and Rollo, 1980; Rothbaum et al., 1982) or animals (Staley et al., 1969; Moon et al., 1983; Peeters et al., 1984) infected by EPEC show ultrastructural alterations similar to those seen here in infected HEp-2 cells. Furthermore, jejunal enterocytes from infants have specific receptors for EPEC endocytosis-inducer adhesins, since the binding of some EPEC strains to enterocytes is specifically inhibited by carbohydrates that block attachment to and internalisation of the same strains by HEp-2 cells (Andrade and Silva, 1987). Thus, infection of HEp2 cells by EPEC seems to provide a useful and reliable model for testing EPEC attachment to and penetration of enterocytes.

HEp-2 monolayers infected with strain 386, which exhibits type 1 pili and endocytosis-inducer adhesins, showed more infected cells and more severe cellular degeneration than cell cultures infected with the non-pilate strains 54 and 68 . 
Scanning electronmicroscopy suggests that pili of strain 386 co-operate in bacterial binding to the cell surface. We showed previously that EPEC with type 1 pili adhered more readily to $\mathrm{HeLa}$ and $\mathrm{HEp}$ 2 cells (Andrade et al., 1984; Andrade and Santa Rosa, 1986b) and to human enterocytes (Andrade and Silva, 1987) than non-pilate EPEC strains. Hydrophobic properties and the spatial arrangement of type- 1 pili could facilitate the initial contact with the cell surface, improving further interaction between endocytosis-inducer adhesins and their

\section{REFERENCES}

Alberts B, Bray D, Lewis J, Raff M, Roberts K, Watson J D (eds) 1983 The cytoskeleton. In: Molecular biology of the cell, Garland Publishing Inc., New York, pp 549-609.

Allison A C, Davies, P, de Petris S 1971 Role of contractile microfilaments in macrophage movement and endocytosis. Nature New Biology 232: 153-155.

Andrade J R C, Canine G A, Parentoni L S, Santa Rosa M R 1984 Pili e aderencia para celulas em Escherichia coli enteropathogenicas. Revista de Microbiologia Sao Paulo 15: 239-245.

Andrade J R C, Santa Rosa M R 1986a Attachment and intracellular penetration of classic enteropathogenic Escherichia coli into Hep-2 cells. Revista de Microbiologia Sao Paulo 17: 53-57.

Andrade J R C, Santa Rosa M R $1986 b$ Investigation on an adhesive property (localised adherence) characteristic of classical enteropathogenic serotypes of Escherichia coli. Revista de Microbiologia Sao Paulo 17: 116-125.

Andrade J R C, Da Silva C C 1987 Endocytosis-inducer adhesins produced by enteropathogenic serogroups of Escherichia coli participate on bacterial attachment to infant enterocytes. Memorias do Instituto Oswaldo Cruz 82: 87-90.

Baldini M M, Kaper J B, Levine M M, Candy D C A, Moon H W 1983 Plasmid-mediated adhesion in enteropathogenic Escherichia coli. Journal of Pediatric Gastro-enterology and Nutrition 2: 534-548.

Calabi O 1970 In-vitro interaction of Shigella flexneri with leukocytes and HeLa cells. Journal of Infectious Diseases 122: 1-9.

Coiro J R R, Weigl D R, Kiselins J, Menezes H, Billota J A T 1972 A new embedding medium (Polylite 8001) for biological material. Ciencia e Cultura 24: 660-662.

Cravioto A, Gross R J, Scotland S M, Rowe B 1979 An adhesive factor found in strains of Escherichia coli belonging to the traditional infantile enteropathogenic serotypes. Current Microbiology 3: 95-99.

Echeverria P D, Chang C P, Smith D 1976 Enterotoxigenicity and invasive capacity of "enteropathogenic" serotypes of Escherichia coli. Journal of Pediatrics 89: 8-10.

Gerber D F, Watkins H M S 1961 Growth of Shigellae in monolayer tissue cultures. Journal of Bacteriology 82: 815822.

Gomes J A, Rodrigues A C, Simoes M, Serafim M B, Pestana de Castro A F 1979 Simplification of methods for the production and storage of specimens to be tested for heatstable enterotoxin of Escherichia coli. Journal of Clinical Microbiology 10: 786-790. specific receptors, thereby increasing the number of internalised micro-organisms and the severity of cell damage.

We are grateful to Dr J.Stephen (Department of Microbiology, University of Birmingham) for reviewing the manuscript. We thank Dr R. D. Machado (Instituto de Biofisica-UFRJ) for helping with scanning electronmicroscopy, Miss M. A. Pereira da Silva for excellent technical assistance, and Mrs M. Farr for typing the manuscript. This work was supported by FINEP, the Brazilian National Fund for Research and Development (grant no. 4.3.85 0310.00) and $\mathrm{CNPq}$, the Brazilian Research Council (grant no. 40.25.97/85 CL).

Hale T L, Bonventre P F 1979 Shigella infection of Henle intestinal epithelial cells: role of the bacterium. Infection and Immunity 24: 879-886.

Hale T L, Morris R E, Bonventre P F 1979 Shigella infection of Henle intestinal epithelial cells: role of the host cell. Infection and Immunity 24: 887-894.

Kihlström E, Edebo L 1976 Association of viable and inactivated Salmonella typhimurium 395 MS and MR-10 with HeLa cells. Infection and Immunity 14: 851-857.

Kihlström E, Nilsson L 1977 Endocytosis of Salmonella typhimurium $395 \mathrm{MS}$ and MR-10 by HeLa cells. Acta Pathologica et Microbiologica Scandinavica Section B 85: 322-328.

Klipstein F A, Rowe B, Engert R F, Short H B, Gross R J 1978 Enterotoxigenicity of enteropathogenic serotypes of Escherichia coli isolated from infants with epidemic diarrhea. Infection and Immunity 21 : 171-178.

Knutton S, Williams P H, Lloyd D R, Candy D C A, McNeish A S 1984 Ultrastructural study of adherence to and penetration of cultured cells by two invasive Escherichia coli strains isolated from infants with enteritis. Infection and Immunity 44: 599-608.

Knutton S, Baldini M M, Kaper J B, McNeish A S 1987 Role of plasmid-encoded adherence factors in adhesion of enteropathogenic Escherichia coli to HEp-2 cells. Infection and Immunity 55: 78-85.

Konowalchuck J, Speirs J I, Stavric S 1977 Vero response to a cytotoxin of Escherichia coli. Infection and Immunity 18: 775-779.

Levine M M et al. 1978 Escherichia coli strains that cause diarrhoea but do not produce heat-labile or heat-stable enterotoxins and are non-invasive. Lancet 1: 1119-1122.

Levine M M et al. 1985 The diarrheal response of man to some classic serotypes of enteropathogenic Escherichia coli is dependent on a plasmid encoding an enteroadhesiveness factor. Journal of Infectious Diseases 152: 550-559.

Levine M M 1987 Escherichia coli that cause diarrhea: enterotoxigenic, enteropathogenic, enteroinvasive, enterohemorrhagic, and enteroadherent. Journal of Infectious Diseases 155: 377-389.

Moon H W, Whipp S C, Argenzio R A, Levine M M, Giannella R A 1983 Attaching and effacing activities of rabbit and human enteropathogenic Escherichia coli in pig and rabbit intestines. Infection and Immunity 41 : 1340-1351.

Nataro J P, Baldini M M, Kaper J B, Black R E, Bravo N, Levine M M 1985 Detection of an adherence factor of enteropathogenic Escherichia coli with a DNA probe. Journal of Infectious Diseases 152: 560-565.

O'Brien A D, LaVeck G D, Thompson M R, Formal S B 1982 
Production of Shigella dysenteriae type 1-like cytotoxin by Echerichia coli. Journal of Infectious Diseases 146: 763-769.

Ogawa $\mathrm{H}$ et al. 1967. Virulence and epithelial cell invasiveness of dysentery bacilli. Japanese Journal of Medical Science and Biology 20: 315-328.

Ogawa H, Nakamura A, Sakazaki R 1968 Pathogenic properties of "entero-pathogenic" Escherichia coli from diarrheal children and adults. Japanese Journal of Medical Science and Biology 21 : 333-349.

Peeters J E, Charlier G J, Halen P H 1984 Pathogenicity of attaching effacing enteropathogenic Escherichia coli isolated from diarrheic suckling and weanling rabbits for newborn rabbits. Infection and Immunity 46: 690-696.

Reynolds E S 1963 The use of lead citrate at high $\mathrm{pH}$ as an electron-opaque strain in electron microscopy. Journal of Cell Biology 17: 208-212.

Rothbaum R, McAdams A J, Gianella R, Partin J C 1982 A clinicopathologic study of enterocyte-adherent Escherichia coli : a cause of protracted diarrhea in infants. Gastroenterology 83: 441-454.

Scaletsky I C A, Silva M L M, Trabulsi L R 1984 Distinctive patterns of adherence of enteropathogenic Escherichia coli to HeLa cells. Infection and Immunity 45 : 534-536.

Serény B 1955 Experimental Shigella keratoconjunctivitis. A preliminary report. Acta Microbiologica Academiae Scientiarum Hungaricae 2 : 293-296.

Staley T E, Jones E W, Corley L D 1969 Attachment and penetration of Escherichia coli into intestinal epithelium of the ileum in newborn pigs. American Journal of Pathology 56: 371-392.

Ulshen M H, Rollo J L 1980 Pathogenesis of Escherichia coli gastroenteritis in man-another mechanism. New England Journal of Medicine 302: 99-101.

WHO Scientific Working Group 1980 Escherichia coli diarrhoea. Bulletin of the World Health Organization 58: 23-36. 